この一言でたちまち私は夢のような甘味な世界から現 実に引戻された. それと共にそれぞれ 19 世紀と 20 世 紀の記念碑的構造物である橋を建設し，今日まで維持し てきた人々のことを思わずには居られなかった. 歴史の 流れの中で後世に残り語りつがれる構造物の建設に携わ るのは土木屋冥利につきる. これこそ私の未だ見果てぬ 夢である. 私の遠い記憶にフォース鉄道橋を舞台にした 映画があった. 最近になってやっとその題名が「37 STEPS」だとわかった.どなたか入手方法を教えていた だけませんか. せめて見果てめ夢を追い続けるために.

(筆者· Tatsuya NAKAGAWA, 正会員)

\section{What was Civil Engineering?}

\section{西川 和 廣}

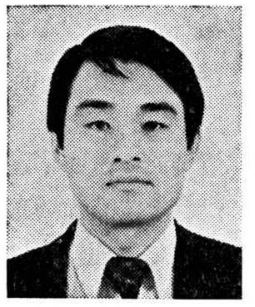

一年程前まで一年間，米国で生 活する機会に恵まれた. 今日の米 国の繁栄が，こんなにも苛酷な自 然条件の上に築きあげられたもの であるとは, というのがそこで最 も強く受けた印象である.

私が滞在していた 1984 年の春 先には, 2 年続いた大雪が融け始め, 各地で河川が氾濫 していた. Colorado 河では, Rocky 山脈の融雪による 流水量がダム系による洪水調節能力を超えることが確実 で, 冷夏を期待するしか洪水を回避する方法はないとの 見通しが早々と公表され, 実際に, あまりにもあっけな く洪水は発生し, 大きな被害を出した.

これが日本であれば，“人災”の二文字が 新聞の紙面 やTV Newsを賑わしたことだろう.ところが，私の見 た限りでは, 報道にそのような論調は見られなかった. 新大陸を開拓してきた米国人は, 自然の力の大きさ, 恐 さをまだ忘れていないんだなとそのとき感じた.

多くの日本人は, 現代の科学技術をもってすれば, 自 然災害を克服すること位たやすいことで，安全というも のは当然与えられているものと考えているのではないだ ろうか. これが誤解であることは，少なくとも土木技術 者の目には明らかである.しかし，このような誤った意 識が生まれてきたことについては，土木技術者側にも責 任の一端があると思う。

かつて土木技術者は，自然の脅威に立ち向かい，国土
を築き上げるとき，民衆のリーダーとしての役割を果し てきたと思う. 決して民衆に安全で快適な生活環境を “与える” 者ではなかった. 最近, 土木技術者は, 自己 の能力を過大評価して後者, すなわち国民の保護者たら んとしているような気がする. 私には,これは“エエカ ッコシイ”かつ “不䞟” な態度だと思えてならない. 土 木技術者だけの力で国土を災害から守り，築き上げるこ とはできない.

われわれ土木技術者が現在持っている技術, 日本の国 土が置かれている現状等を適切にP R , 国民の理解と 協力を得るための努力がもっと払われてもよいと思う.

(筆者・Kazuhiro NISHIKAWA, 正会員 建設省土木研究所)

\section{海外工事における What is Civil Engineering?}

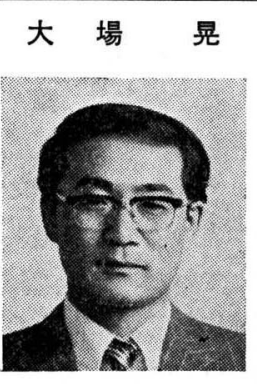

私は昭和 45 年に入社し, 53 年 より香港に 6 年, シンガポールに 1 年, の約 7 年間海外工事に携わ って来ました．第一線に立って現 地で施工を担当する Civil Engineer にとって「海外工事におけ る, What is Civil Engineering?」に対する私なりに学んだ事を述べて見たいと思 います.

最初の香港において先輩より「お前は Civil Engineer だここは日本ではないぞ」と言われ，反面「俺達は外 国人だ，この仕事は本来この国の人達自身の力で完成さ せるべきものなのだ. ただ俺達は彼等が持っていない, 出来ない, テクニカル, ファィナンス等の面で手伝いを しているのだ」と, 教えられました. その時は良く意味 が解りませんでしたけれど. 香港, 英国のカサの下にい て中国の意志の下に㗢いている国, その次の国, シンガ ポール “熱帯の奇跡”と言われ，建国 25 年にして大発 展を遂げた小さな島国, 何と違いの大きい事か！同じ 海外工事であり，同じ地下鉄工事であり，似た様な契約 条件の下で働いているのに, クレームの問題一つ取り上 げても, 出発点は同じなのにアプローチの仕方の違う 事, 相手の反応の違う事, こう言う違いは契約書の違い よりも，その当事国の違いから来る様です. しかしなが 